AN INTRODUCTION TO GROUPWORK 


\section{BASIC TEXTS IN COUNSELLING AND PSYCHOTHERAPY}

Series editor: Stephen Frosh

This series introduces readers to the theory and practice of counselling and psychotherapy across a wide range of topic areas. The books appeal to anyone wishing to use counselling and psychotherapeutic skills and are particularly relevant to workers in health, education, social work and related settings. The books are unusual in being rooted in psychodynamic and systemic ideas, yet being written at an accessible, readable and introductory level. Each text offers theoretical background and guidance for practice, with creative use of clinical examples.

\section{Published}

Jenny Altschuler

WORKING WITH CHRONIC ILLNESS

Bill Barnes, Sheila Ernst and Keith Hyde

AN INTRODUCTION TO GROUPWORK

Stephen Briggs

WORKING WITH ADOLESCENTS AND YOUNG ADULTS 2nd Edition

Alex Coren

SHORT-TERM PSYCHOTHERAPY 2nd Edition

Jim Crawley and Jan Grant

COUPLE THERAPY

Emilia Dowling and Gill Gorell Barnes

WORKING WITH CHILDREN AND PARENTS THROUGH SEPARATION AND DIVORCE

Loretta Franklin

AN INTRODUCTION TO WORKPLACE COUNSELLING

Gill Gorell Barnes

FAMILY THERAPY IN CHANGING TIMES 2nd Edition

Fran Hedges

AN INTRODUCTION TO SYSTEMATIC THERAPY WITH INDIVIDUALS

Fran Hedges

REFLEXIVITY IN THERAPEUTIC PRACTICE

Sally Hodges

COUNSELLING ADULTS WITH LEARNING DISABILITIES

Linda Hopper

COUNSELLING AND PSYCHOTHERAPY WITH CHILDREN AND ADOLESCENTS

Sue Kegerreis

PSYCHODYNAMIC COUNSELLING WITH CHILDREN AND YOUNG PEOPLE

Ravi Rana

COUNSELLING STUDENTS

Tricia Scott

INTEGRATIVE PSYCHOTHERAPY IN HEALTHCARE

Geraldine Shipton

WORKING WITH EATING DISORDERS

Laurence Spurling

AN INTRODUCTION TO PSYCHODYNAMIC COUNSELLING 2nd Edition

Paul Terry

COUNSELLING AND PSYCHOTHERAPY WITH OLDER PEOPLE 2nd Edition

Jan Wiener and Mannie Sher

COUNSELLING AND PSYCHOTHERAPY IN PRIMARY HEALTH CARE

Shula Wilson

DISABILITY, COUNSELLING AND PSYCHOTHERAPY

Steven Walker

CULTURALLY COMPETENT THERAPY

Jenny Walters

WORKING WITH FATHERS

Jessica Yakeley

WORKING WITH VIOLENCE

Invitation to authors

The Series Editor welcomes proposals for new books within the Basic Texts in Counselling and Psychotherapy series. These should be sent to Stephen Frosh at the School of Psychology, Birkbeck College، Malet Street,

London, WC1E 7HX (e-mail s.frosh@bbk.ac.uk)

\section{Basic Texts in Counselling and Psychotherapy \\ Series Standing Order ISBN 978-0-333-69330-8}

(outside North America only)

You can receive future titles in this series as they are published by placing a standing

order. Please contact your bookseller or, in the case of difficulty, write to us at the

address below with your name and address, the title of the series and the ISBN quoted above.

Customer Services Department, Macmillan Distribution Ltd

Houndmills, Basingstoke, Hampshire RG21 6XS, England 


\title{
AN INTRODUCTION TO GROUPWORK
}

A Group-Analytic Perspective

\author{
Bill Barnes, Sheila ERNSt \\ and \\ KEITH HyDE
}




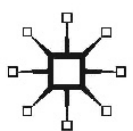

(c) The Estate of Bill Barnes, Sheila Ernst and Keith Hyde, 1999

All rights reserved. No reproduction, copy or transmission of this publication may be made without written permission.

No portion of this publication may be reproduced, copied or transmitted save with written permission or in accordance with the provisions of the Copyright, Designs and Patents Act 1988, or under the terms of any licence permitting limited copying issued by the Copyright Licensing Agency, Saffron House, 6-10 Kirby Street, London EC1N 8TS.

Any person who does any unauthorised act in relation to this publication may be liable to criminal prosecution and civil claims for damages.

The authors have asserted their rights to be identified as the authors of this work in accordance with the Copyright, Designs and Patents Act 1988.

Published by

PALGRAVE MACMILLAN

Palgrave Macmillan in the UK is an imprint of Macmillan Publishers Limited, registered in England, company number 785998, of Houndmills, Basingstoke, Hampshire RG21 6XS.

Palgrave Macmillan in the US is a division of St. Martin's Press LLC, 175 Fifth Avenue, New York, NY 10010.

Palgrave Macmillan is the global academic imprint of the above companies and has companies and representatives throughout the world.

Palgrave ${ }^{\circledR}$ and Macmillan ${ }^{\circledR}$ are registered trademarks in the United States, the United Kingdom, Europe and other countries.

ISIN 978-0-333-63224-6 ISBN 978-1-349-90745-8 (el3ook)

DOI 10.1007/978-1-349-90745-8

This book is printed on paper suitable for recycling and made from fully managed and sustained forest sources. Logging, pulping and manufacturing processes are expected to conform to the environmental regulations of the country of origin.

A catalogue record for this book is available from the British Library. 


\section{CONTENTS}

Foreword by Jeremy Holmes

viii

Acknowledgements

xiii

\section{Introduction}

Looking at groups: what is a group-analytic approach? 1

Defining a Group 2

Observation as the Starting Point 3

A Way of Classifying Groups 5

What a Group-analytic Approach Means 9

Understanding What Happens in Groups $\quad 10$

A New Pair of Glasses 11

\section{The Individual and the Group}

Group therapy from the individual's point of view: how can it help me, or my client/patient?

Introduction 15

Part 1: Drawing Ideas from Psychoanalysis 16

Part 2: Applying Group Concepts to the

Experience of the Individual 23

3 Growing a Group 29

Introduction 29

Growing a Group $\quad 30$

Planning and Negotiating within the Organisation 32

Defining the Therapist's Task in the Group 35

Selecting the Members 38

Preparation 44

The Conductor $\quad 46$

Starting Out: A Summary $\quad 49$ 
4 What Happens in a Group?

The development of the group: illustrated with an account of the life of one group

Introduction

Clinical Presentation 53

Middle Phase in Group Development 67

Subgroups Emerge: The Transition to the Mature Group 72

$\begin{array}{ll}\text { The Mature Group } & 75\end{array}$

$\begin{array}{ll}\text { The Final Session } & 80\end{array}$

5 Working in the Group

Part 1: Negotiating the boundaries $\quad 82$

Introduction $\quad 82$

Joining the Group $\quad 82$

Working at the Boundary $\quad 85$

Patrolling the Boundary $\quad 89$

Separating from the Group $\quad 94$

Endings in Groups $\quad 96$

6 Working in the Group

Part 2: Interventions and interpretations; therapeutic activity 101

Introduction 101

The Conductor Orientates Herself in the Group 102

The Conductor Intervenes to Enhance the

Therapeutic Factors in the Group 106

Thinking About and Intervening in Group Processes $\quad 110$

Some Types of Intervention in Group Analysis $\quad 115$

Some Theoretical Underpinnings of Group Therapy 116

$\begin{array}{ll}\text { Interpretation } & 117\end{array}$

Group Focal Conflict Theory 119

The Dynamics of Group and Individual Systems 120

The Conductor Intervenes: An Overview 123

7 Differences in Groups: Heterogeneity and Homogeneity 125

Introduction $\quad 125$

The Psychology of Difference 126

Working with Differences in Groups 129

Homogeneous Groups $\quad 138$

Conclusions 143 
8 Working Together

Applying an understanding of groups in the workplace

Introduction

Working Together

Psychoanalytic Ideas about Organisations and some

Parallels with Group Processes

Applying Group-analytic Thinking to the Workplace:

The Role of Consultation

Similarities and Differences between

Consultation and Group Therapy

Thinking about the Whole Organisation

Conclusion: Group Analysis and Group Relations

9 On Becoming a Group Therapist

Introduction

The Orientation of the New Group Therapist

Tools for Development

Person and Role

Selected Organisations and their Addresses

Training Organisations offering Advanced Group-analytic Training

Training Organisations offering Specialist

Group-analytic Training 


\section{FOREWORD}

\section{Simplicity, complexity and applying the group-analytic approach}

Groups are by their nature complex and multifaceted. One of the great merits of this book, as the reader will discover, is that it manages to simplify what is at times an overwhelmingly confusing subject. A group experience can perhaps be divided into three phases. At the start the participants arrive with simple and often stereotyped views: 'This group is going to get me better, my doctor told me so'; 'This staff group is out to psychoanalyse me, no way am I going to let it'; 'That group leader is a cold fish, I certainly can't trust someone who refuses to answer simple questions', or 'We are here to solve our problems, let's get on with it'. There then follows a period in which all seems confusion and uncertainty. How can one possibly make sense of such a profusion of views and feelings and interactions? Far from problems being solved, they seem to multiply. There appears to be no way forward. A silence descends upon the group, or one member talks incessantly. The very existence of the group seems threatened, especially if the following week one or two members fail to turn up.

The group members (and the conductor) have to immerse themselves in this maelstrom and survive. In the end, however, the meaning of the group often emerges in a surprisingly simple way. Someone will make a clarifying remark, or reveal their feelings in an open and honest way, or make a simple suggestion, and the fog suddenly clears and, for the moment at least, all seems to make sense. Participating in such a group experience can be profoundly moving and humbling. It is as though the electricity in the group, often contradictory and dangerous, suddenly earths through one individual who, through a simple remark 'I feel frightened', or 'Why don't we try it this way?' - moves the feelings and discussion on to a deeper level.

The great innovators in group analysis have mirrored this living experience of groups in their theoretical thinking. Bion's classification 
into work group, flight or fight, pairing, and dependency is so elegant and simple and yet has a universal applicability which, despite numerous attempts, has yet to be bettered. Another deceptively simple notion is that of Foulkes - of the setting and its uses. The regularity of time and place, the arrangement of chairs, the punctuality, the announcement of breaks, the rules of confidentiality, anonymity, and openness - all these form a framework and a boundary, an arena and a space within which emotional life can be played out. The interactions between the individual group member and the setting - lateness or overpunctuality, the wish to contact other members outside the group, where one chooses to sit - are manifestations of the complexity of the individual psyche and its interactions with other psyches within the group. It is the task of the conductor to comprehend these links and to communicate them in a simple way to the group.

This dialectic is nowhere more evident than in a large organisation such as a hospital or mental health unit. I believe that group analysis has an invaluable part to play in the running of such an organisation. Units like these usually run on simple hierarchical principles - lines of responsibility, converging eventually on a leader such as chief executive or clinical director. In the UK successive waves of government policies have shaped the way in which these organisations function: supervision registers, the care programme approach, primary nursing, risk management. Organisational anxiety is handled in the classic Menzies-Lyth (1959) fashion (see Chapter 8). A complex bureaucratic structure is created to give the appearance that something is being done. This is not to say that some of these innovations cannot be useful in systematising thought and avoiding lackadaisical or risky work practices. But from a group-analytic perspective, of which this book is such a fine exposition, they avoid two main issues. First, this 'paperwork' gives the impression that, if procedures are rigorously followed, all will be well. Mental pain, disaster, death, loss, disability, mistakes and perversion will somehow be miraculously swept aside, only to recur if procedures have been incorrectly pursued. Second, paperwork becomes a substitute for the mental work of the group - the work of containing fears and anxieties on a collective basis, of facing inadequacy, the partial successes which are often the best that can be hoped for, the inevitable relapses and failures.

There is indeed an irony in this: the more the group is able to face its weaknesses, the stronger it becomes; the more it can admit to fears and failures, the less likely failure is to occur. This may seem an unsubstantiated claim, but there is good evidence that running a staff group on an acute admission ward in itself reduces the incidence of untoward 
'incidents' so feared by management. The mechanism by which this happens needs further research - is it more open communication between staff members, clarification of lines of responsibility and leadership, greater security for patients in knowing that the staff support each other and so are more able to hold projections?

A staff group on an admissions ward or community mental health team can be a fragile thing. Workers are often suspicious, or contemptuous: 'They are in there for hours on end contemplating their navels, while we out here are doing the real work.' The management may view such groups as subversive, ambivalently damning the group with faint praise, or asking for endless evaluation sheets to be filled in by all participants before they can let it go ahead. Such groups can be divisive, however much their overt aim is the opposite - the ward can be split into 'groupies' and those who refuse to participate. Membership can fluctuate wildly. Talking in groups can become a substitute for clear treatment plans and decisive leadership. The simple can get bogged down in the complex. The value of such a group will emerge slowly over time, and may not be apparent to those looking for instant results. Anyone planning to set up such a group will do well to read a book such as this which emphasises the need for careful planning, forming an alliance with key figures in an organisation, and being sensitive to the inevitable threat that a small pocket of space in which anxiety can be exposed and held will create in an organisation dedicated to its suppression. It is all too easy to blame 'them' - the management, the insensitive ward manager, the suspicious consultant psychiatrist - so losing hold of the basic group-analytic principle that negative aspects of group phenomena will often be carried by one or two individuals, and disowned by the group as a whole.

A similar process of projection applies to psychiatry itself, especially in a general hospital setting, which within medical culture is often seen as the repository for all that is uncomfortable, awkward, untreatable and emotional - the psychic equivalent of the clinical waste department where difficult feelings can be located so that the rest of the hospital can run with its accustomed smooth sterility. The main function of acute psychiatric wards is containment of threats of disturbance or violence to self or others. One might cynically suggest that that, ultimately, is why governments fund psychiatric services at all. Through early intervention and 'assertive outreach' many patients who previously would have been admitted to such wards are now contained in the community by teams of intensive carers, working in the patients' home. There is much debate in psychiatric circles about how many in-patients beds are needed, 
although all admit that there is a residuum without which psychiatric services cannot function effectively over long periods. How do such services 'work'? Partially of course it is the new anti-psychotic and antidepressant medications. Partially it is the specific psychological interventions such as reduction in family anxiety or helping psychotic patients to live with their delusions. But perhaps more important than both of these is the strength of the group in reducing anxiety and helping the sufferer to feel held and supported. Research has shown that psychological distress reduces following hospital admission long before the drugs have had time to take effect. A vital task of the organisation is to harness the containing power of groups. This applies both in in-patient settings and in the community, where mental health workers can only function effectively if they are true teams, working together to a common task, supporting each other, exploring and reconciling differences when they arise.

It is all too easy to see only the instrumental aspects of such work the tasks of delivering 'packages' of care, and to miss the matrix out of which these arise, and which, if malfunctioning, can undermine the whole enterprise. Many ward staff offer their patients counselling or group therapy sessions, and these can certainly be valuable. But if the overall milieu of the ward is dysfunctional - if staff do not communicate, if there is splitting, if leadership shirks its tasks - then all is undermined. A ward or community team is like a family, and the principles of healthy family function can be applied to it. There needs to be a clear leadership structure, with good communication and mutual respect between men and women. The clients/patients, like children in a family, need to know where they are and where the boundaries lie. At the same time there needs to be a warm atmosphere of open communication, acceptance, and a culture of humour and fun. A psychologically dysfunctional ward, like a surgical ward infested with multiple drugresistant bacteria, may begin to cause the very disturbances it purports to cure. Dependency becomes rife, patients learn to express distress via cutting and overdosing rather than through open communication, an 'adolescent' feel to the culture begins to build up in which staff are seen as dictatorial and neglectful, the patients impossible and 'bad'. The idea of psychiatric illness gets lost and a culture of 'blaming the victim' develops. In these conditions of 'malignant alienation' suicides are most likely to occur. Written protocols may help to some extent in 'risk management', but if the ward atmosphere is wrong, and there is no systematised group forum such as a staff support group where difficult 
issues can be discussed openly, the likelihood that mistakes will happen is greatly increased.

In my view the use of group-analytic principles in staff support in psychiatric settings, and where possible median groups for patients and staff together, is an essential counterpoise to balance the emphasis on focused interventions and protocols that are currently so fashionable. There is a danger that the skills needed to run - or even to participate in - such groups will atrophy under a welter of regulatory paperwork. These skills are not simply those of 'interpersonal technology' or 'psychosocial interventions', but a mature capacity to reflect on oneself in relation to others - the ability to understand and work with transference and countertransference. This timely book is a significant contribution to the growing recognition of the importance of psychotherapy in all its forms as part of a modern psychiatric service. A basic principle of psychotherapy is the importance of relationships as fundamental to human health. The individual in relationship to groups - the family, work groups and the wider society - is the province of group analysis. The social nature of man is a simple truth, whose complex implications are explored with almost deceptive clarity throughout this volume.

JEREMY HOLMES, MD MRCP, FRCPSych

Consultant Psychotherapist, North Devon and Chair of the Psychotherapy Faculty, Royal College of Psychiatrists 


\section{ACKNOWLEDGEMENTS}

This book is dedicated to Bill Barnes who died, prematurely, before its publication. Bill represented an important element in our project because, like many of our prospective readers, he was not a group analyst. He was a very experienced group clinician, a knowledgeable theoretician and teacher who used a group-analytic understanding in his clinical practice, in supervision and as the clinical director of a consultation and psychotherapy service. He encompassed a complex approach to psychotherapy which we hope this book will encourage in its readers.

Completing the work the three of us had started together, as staff members of the Manchester Course in Group Psychotherapy, in the shadow of Bill's illness and untimely death was a painful experience.

We hope that this book reflects the tradition of the Institute of Group Analysis which over the past twenty-five years has offered courses to thousands of students who work in groups using diverse approaches, but have found that group-analytic thinking had something special to offer them in their understanding of groups.

We would like to thank the many students who over the years have attended the Manchester Course in Group Therapy and in particular those group members who agreed to the publication of their group. Without these students the book could not have been written. We were delighted to be asked by Stephen Frosh to contribute to the series and have appreciated his patience and encouragement, despite his misgivings about the group writing of a book on groups.

Sheila ERNST AND KeITH Hyde

Every effort has been made to trace all the copyright holders but if any have been inadvertently overlooked the publishers will be pleased to make the necessary arrangements at the first opportunity. 